\title{
Mental Disability in Islamic Jurisprudence from a Moral Perspective
}

\author{
Dr. Muḥammad Fawzy Hasan 'Abdel-Hay
}

Faculty of Languages and Translation

Department of Islamic Studies in Foreign Languages 


$$
\begin{aligned}
& \text { مختصر: تبحث هذه الورقة موقف الفقهاء من المعاقين عقليا، فتعرض للمصنفات الأدبية والفقهية الخاصة بالإعاقة العقلية }
\end{aligned}
$$

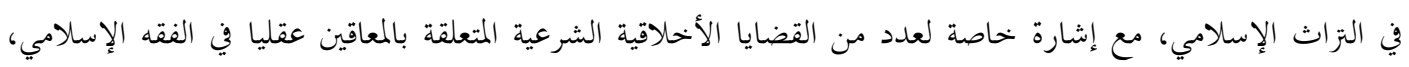

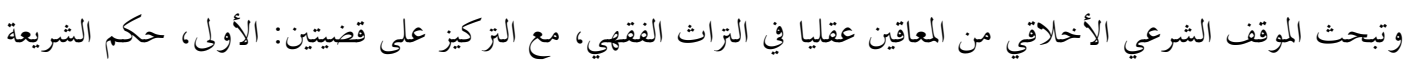

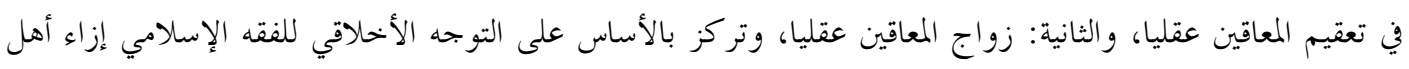

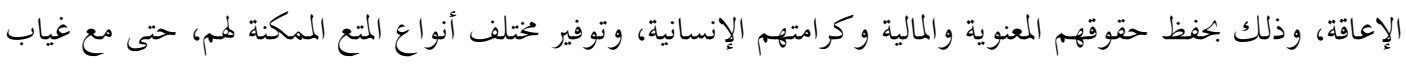

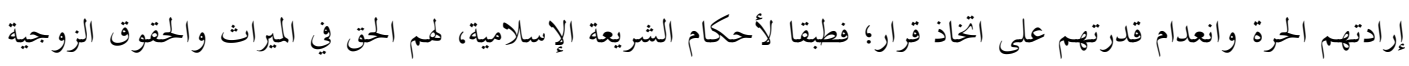

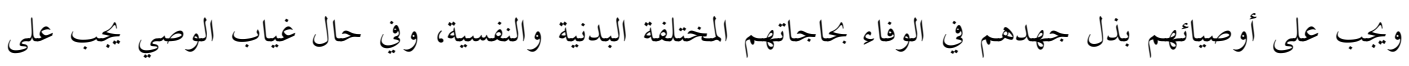

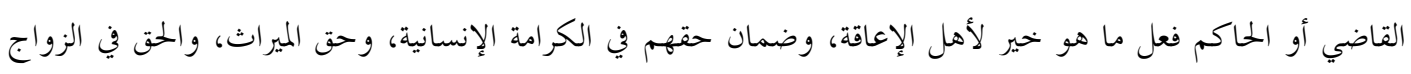

Abstract: This paper examines the juristic stand concerning people with mental disability and presents a brief account of the literary and juristic literature written on mental disability in Muslim tradition with focus on a number of the ethico-legal issues related to persons with mental disability. It mainly investigates the ethical and legal position concerning the persons with mental disability in Muslim juristic tradition and presents an analysis of the juristic views on various questions related to them with concentration on two critical issues: first, the Sharia ruling on the sterilization of persons with mental disability; and second, the marriage of persons with mental disability. The paper highlights the moral attitude of Islamic Jurisprudence regarding people with disability as safeguarding their moral and financial rights and human dignity as well as providing them with all possible kinds of legal enjoyments even in the absence of their freewill and ability to make a decision. Under Islamic laws, they have the right to inheritance and marital rights, and their guardians shall give due care to meet their different physical and psychological needs. In the absence of a close guardian, the judge or the ruler shall undertake the duty of considering the best interest of people with mental disability, including their fundamental rights to human dignity, financial rights, and the right to marriage and procreation.

\section{Keywords: Disability - Mental disability - Mental Retardation - Persons with Disability - Islamic Jurisprudence - Sterilization - Marriage}




\section{Introduction}

The rights of persons with disability have become of keen interest throughout the world over the last decades. As a sign of this ever-increasing attention, the UN has issued a number of documents, resolutions, and declarations for the protection and enhancement of the Rights of Persons with disabilities. For example, the UN General Assembly proclaimed the Declaration on the Rights of Mentally Retarded Persons in December 1971 CE, the Declaration on the Rights of Disabled Persons in December 1975, and declared the year 1981 as the International Year of Disabled Persons. The General Assembly then adopted the World Programme of Action concerning Disabled Persons in 1982. Since then, endeavors and steps for the empowerment of persons with disability continued and were culminated in the UN General Assembly proclamation of the Convention on the Rights of Persons with Disabilities in December 2006, a very important step that paved the way for several others.

In response to this momentum, several conferences, seminars, and activities have been held to explore the rights of people with disability and address the problem of exposing them to exclusion worldwide. Writings on the issue have been attracting many writers east and west. In this regard, the Arab region is not exceptional. Actually, the people with disability occupy a remarkable part of the Arabic library and Muslim heritage in terms of their contributions, literature, legal discussion, and literary symbolism, let alone their living presence and inspiring figures in modern educational and religious reformation. This paper then endeavors to present a reading of the Muslim tradition and ethical Islamic rulings regarding people with mental disability in particular.

Actually, disability is a natural phenomenon declaring an aspect of imperfection for humankind to perceive the value of perfection and offer thanksgiving to the Lord. ${ }^{1}$

1 In this context, Ibn al-Jawzi (d. 597 AH/1201 CE) mentions that when Allah created Adam and showed him his future children, Adam found some blind, some deaf, and others affected by forms of disability. He asked, "O Lord, why did You not create them all equal-perfect?" In response, the Lord said, "I wanted to be thanked." See, Ibn al-Jawzi, Abu al-Faraj 'Abd al-Raḥmān al-Baghdadi (d. 597 AH/1201 CE). "Akhbār al-Hamqa wal Mughaffalīn" with commentary by 'Abd al-Amīr Muhanna, (Beirut: Dar al-Fekr al-Libnāni, 1410 AH/1990 CE), p. 13. 
In other words, imperfection leads a person to realize the essence and loftiness of perfection, so a human being would appreciate the divinelygranted blessings as should be. The fact that a person suffers a certain disability should not be seen as a basis to deny their rights to good life or even as barrier to any possible human achievements they can do. Several individuals with disability excelled millions of able-bodied persons and did great contributions to human arts and scientific research. Names of outstanding disabled persons like Abu al-'Alā' al-Ma'arri (363-449 AH/9741058 CE), ${ }^{2}$ 'Ali Ibn Isma‘ ‘̄l Ibn Sīdah (d. 458 AH/1066 CE), ${ }^{3}$ Bash-Shār Ibn Burd (d. 168 AH/783 CE), ${ }^{4}$ Vincent Willem van Gogh (1853-1890), 5 Ṭaha Hussein (1889-1973 CE), ${ }^{6}$ and Stephen William Hawking (1942 - 2018) ${ }^{7}$ are widely influential and truly unforgettable.

This research discusses only one kind of disability; namely, the mental disability. It presents an outline about words used for mental disability in

2 He is a famous poet and writer whose literature has been widely translated and given worldwide recognition - had been affected by smallpox, which cost him his sight, but he proved an exceptional talented writer, critic, and man-of-letters. He was quoted to have said, "I thank God for blindness as others thank Him for the blessing of sight." See, e.g., Ibn Kathīr, al-Bidayah wa al-Nihayah. Edited by Salah alKheimi, (Qatar: Ministry of Awqaf and Islamic Affairs, 1436 AH/2015 CE), vol. 13, p.132-134; al-Sharabāṣi, Aḥmad, Fi Alam al-Makfufin, (Cairo: Maṭba'at Nahḍat Mișr, 1375 AH/1956 CE). p. 338 ff; Ibn 'Abd al-Rạ̣man, Abu al-Fath al-'Abbasi 'Abd al-Rahim (d. 963 AH/1556 CE), Ma'ahid al-Tanșiṣ Ala Shawahid al-Talkhīṣ. Edited by Muhyiddīn 'Abd al-Hamīd, (Beirut: 'Alam al-Kutub, undated), vol. 1, p. 137; al-Sharabāṣi, Fi 'Alam al-Makfufin, p. 340.

3 He is a notable lexicographer and linguist widely known for his great contributions to lexicography and commentaries on poetry despite being born blind. See, e.g., Abu al-Qasim Ibn Ibn Bashkawāl (d. 578 AH/ 1183 CE), al-Ṣilah fi Tarīkh A'immat alAndalus. Edited by Bash-shār Ma'rūf, (Tunis: Dar al-Gharb al-Islami, $2010 \mathrm{CE}$ ), vol.2, p.33.

4 Ibn al-Mu'taz, Tabaqāt al-Shu 'arā'. Edited by 'Abd al-Sattār A. Farraj, (Cairo: Dar al-Ma'ārif, $3^{\text {rd }}$ ed. undated), p. 21-22; Ibn Khillikān, Wafayāt al-A yān. Ed. Iḥsān 'Abbas, (Beirut: Dar Șadir, 1398 AH/1978 CE), vol.1, p.271-272.

$5 \mathrm{He}$ is an influential figure in the history of Western art and had a kind of mental disability. See, e.g., https://en.wikipedia.org/wiki/Vincent_van_Gogh.

6 Despite his blindness, he was a very prominent Egyptian writer during the $20^{\text {th }}$ century. See, e.g. https://en.wikipedia.org/wiki/Taha_Hussein.

7 He held the Lucasian Professor at Cambridge, the chair held by Isaac Newton in 1663. Professor Hawking received over a dozen honorary degrees and was awarded the CBE in 1982. He was a fellow of the Royal Society and a member of the US National Academy of Science. See, e.g., http://www.hawking.org.uk. 
Arabic and examples of books about the issue in Muslim tradition. It then examines the ethical stand of Muslim jurists and Islamic laws concerning the rights of people with mental disability to receive financial rights, get married, and have children, given the absence of their mental powers to take decisions. The research depends on the descriptive, analytical, and critical approaches in an attempt to present a juristic discussion on mental disability and focus on a number of serious modern issues from an ethico-legal approach. 


\section{Mental disability in the Quran and Arabic Literature}

The Quran includes several indications to different categories of persons with disabilities revealed in various contexts $;{ }^{8}$ some are didactic and preachy whereas others are exemplary or legislative. However, the Arabic word "i 'aqah i.e. disability" has not been mentioned in the Islamic texts. Only the agent noun (in Latin, nomen agentis) "mu'awwiqin, i.e. those who hinder or discourage" - is used in the plural form in the Glorious Quran: "Allah knows well those holding others back" (Quran, 33: 18). Evidently, the verse refers to those who create kinds of spiritual disability in souls of the believers, holding them back from taking active part in struggle against the aggressive enemies. ${ }^{9}$

As for the words used for mental disability, the Arabic language is rich with words related to this semantic field. The most famous word in this context is "junün" (جنون), which literally signifies the absence of mind or rather the absence of the power of reason itself. The Quran uses the word

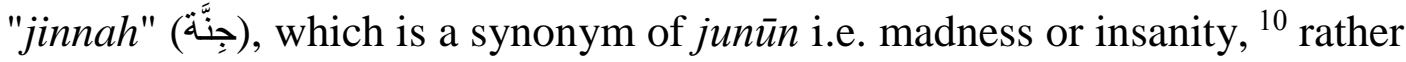
than junīn in four verses. ${ }^{11}$ They all refute the doubts that the disbelievers attempted to raise about the mental powers of Prophet Muhammad and Prophet Noah declaring that the cause of such calumny is disbelief and arrogance. ${ }^{12}$ Jurists classify junūn into two forms: i) a congenital insanity,

$8 \quad$ See, e.g., the Quran, 2: 18; 24: 62; 48: 17.

9 Ibn Hisham, al-Sirah al-Nabawiyyah. Ed. Mușțafa Al-Saqqa et al., (Cairo: Mușțafa al-Babi al-Halabi Press, 1375AH/1955 CE), vol. 2, p. 224; Samuel M. Jackson, The Concise Dictionary of Religious Knowledge and Gazetteer, (New York: 1889), p. 599; al-Tabari, Muhammad Ibn Jarīr, Jami`al-Bayān. Edited by Ahmad Shaker, (Beirut: Muassasat al-Resalah, 1420 AH), vol. 20, p. 230.

10 Al-Fayyūmi, Aḥmad Ibn Muḥammad (d. 770 AH/1368 CE), al-Mișbāḥ al-Munīr fi Gharīb al-Sharḥ al-Kabīr. Edited by Dr. 'Abd al-'Aẓ̄m al-Shinnāwi, (Cairo: Dar alMa'arif, $2^{\text {nd }}$ ed. undated), p.112.

11 The Quran, 7: 184; 23: 25, 70; 34: 8. Note that the same word is used in reference to the jinn in other verses as they are hidden beings (e.g., the Quran, 11: 119; 37: 158; 114: 6). See, 'Abd al-Baqi, Muhammad Fuad, al-Mu'jam al-Mufahras Li AlfāzalQuran al-Karìm, (Cairo: Mațabi' al-Sha'b, undated), p. 180; al-Fayrūzabadi, Majd al-Dīn Muḥammad Ibn Ya'qūb (d. 817 AH/1415 CE), Bașa'er Dhawi al-Tamyīz fi Lața'ef al-Kitāb al-'Azìz. Edited by Muhammad A. al-Najjār, (Cairo: Ministry of Awqāf, 1416 AH/1996 CE), vol.2, p.353.

12 For example, Allah says in relation to the claims of disbelievers about Prophet Muhammad, "Do they say that there is in him a touch of madness? Rather he has brought them the truth, and most of them are haters of the truth" (the Quran, 23: 70) 
which is incurable; and ii) an accidental insanity arising from psychological disorders, which is curable. They also classify it into permanent without any detainment of consciousness and temporary. ${ }^{13}$

It is from the same root that the Arabs used the noun "jinn" (جن) as a name for the invisible beings and the noun janin (جَنين) for the fetus, since they both are hidden from human eyes. As such, they called a person affected by mental derangement majnün, for his reason is covered or overcome $^{14}$. The word majnūn (fem. majnūnah) occurs eleven times in the Quran, which come in the context of relating the false account of the disbelievers about Prophets: Noah, ${ }^{15}$ Moses, ${ }^{16}$ and Muhammad. ${ }^{17}$ For examples, Allah says, "Likewise, no messenger came to those before them but they said: A magician or a majnūn i.e. madman!"18 Another verse declares, "Before them, the people of Noah denied (their Prophet Noah); they then belied Our servant and said: "majnūn i.e. a madman!"19

In this context, the Arabic have some other words used for a person with mental disability or mental weakness, even if the majūn is the most famous term. The Arabs also use the word " $m a$ 'tuh" (معتوه) in reference to a person with a weak mental ability. For Ibn Habīb, the ma 'tūh signifies a person with congenital mental disability. ${ }^{20}$ The ahmaq (fem. hamqāa' is another literary word widely used in reference to a foolish person exhibiting a lack of right judgments and common sense. Hamiqa is

Allah also says, "Say [O Muhammad to them], 'I advise you to do one thing only: stand before Allah, in pairs or singly, and think: there is no sign of madness in your companion [the Prophet]. He is only a warner to you ahead of a severe punishment" (the Quran, 34: 46).

13 See, al-Bukhari, 'Abd al-'Az̄̄z Ibn Ahmmad (d. 730 AH/1330 CE), Kashf al-Asrār 'An Ușūl Fakhr al-Islam al-Bazdawi, (Beirut: Dar al-Kitāb al-'Arabi, undated), vol.4., p. 263.

14 Ibn Habīb, 'Uqalā' al-Majanīn, p.43; Ibn 'Abidīn al-Hanafi, Muhammad Amin Ibn 'Umar, (d. 1252AH/1836 CE), Radd al-Muhtār 'Ala al-Durr al-Makhtār, (Beirut: Dar al-Fekr, 1412 AH/1992 CE), vol.2, p. 258.

15 The Quran, 54: 9.

16 The Quran, 26: 27; 51: 39.

17 The Quran, 15: 6; 37: 36; 44: 14.

18 The Quran, 51: 52.

19 The Quran, 54: 9.

20 Ibn Habīb, 'Uqalā' al-Majanīn, p.43; Ibn 'Abidīn al-Ḥanafi, Muhammad Amīn Ibn 'Umar, (d. 1252AH/1836 CE), Radd al-Muhtār 'Ala al-Durr al-Mukhtar, (Beirut: Dar al-Fekr, 1412 AH/1992 CE), vol.2, p. 258. 
also another form of the same root conveying the same meaning. ${ }^{21}$ Another similar term is ahkraq (fem. Kharq $\bar{a}$ 'أخرق ومؤنثه خرقاء), which is identical with ahmaq. ${ }^{22}$ The akhraq may also be identical with the word mad-hush (مدهوش), which refers to a person with an astounded or shocked mind as a result of fears or embarrassment, ${ }^{23}$ even if s/he suffers no insanity. ${ }^{24}$ The term ablah (fem. balhā' أَبْله ومؤنثَه: بَلْهاء) derived from the verb baliha i.e. to be of weak mind, is widely in usage. ${ }^{25}$ There is also the maghmur al- 'aql (مغدور العَقل), which signifies a person whose mental ability is overcome and covered. ${ }^{26}$ The famous philologist Abu Manșūr al-Tha'alibi (d. 429 AH/1038 CE) states in his most known work "fiqh al-Lugha" that the one affected by the lowest degree of mental retardation is called muwaswas whereas the one affected by the lowest degree of absurdity is called ablah. If such degree escalates to an imprudently reckless behavior, a person affected is called akhraq. ${ }^{28}$ There is also the word safih (سَفِيه), which the Quran ${ }^{29}$ uses for sane, yet unwise and imprudent, persons. ${ }^{30}$ To conclude, the Muslim linguists specify certain terms for certain meanings, which the jurists shall observe while qualifying the legal status of various persons with mental

$21 \quad$ Al-Fayyūmi, al-Mișbāḥ al-Munīr, p.151.

22 Ibn 'Abd al-Hadi, Yusuf Ibn Hasan (d. 909 AH/1503 CE), al-Durr al-Naqi fi Shah Alfāz al-Khiraqi. Edited by Raḍwān Gharbiyyah, (Jedda: Dar al-Mujtama', 1411 AH/1991 CE), p. 587-588.

23 Al-Fayyūmi, al-Mișbāh al-Munīr, p.167.

24 Ibn 'Abidīn al-Hanafi, Radd al-Muhtār 'Ala al-Durr al-Mukhtār, vol.2, p.258.

25 Al-Fayyūmi, al-Mișbāh al-Munīr, p. 61.

26 Al-Asbuhi, Malik Ibn Anas (d. 179AH/795 CE), al-Mudawwanah, (Beirut: Dar alKutub al-'Ilmiyyah, 1415 AH/1995 CE), vol.2, p.84.

27 Arabic has several terms usually used for light junūn, such as lamam, khiffah, waswasah, and khayfah. They all refer to weak understanding and clumsy behaviors. See, al-Hamadhāni, 'Abd al-Raḥmān Ibn 'Isa, Kitāb al-Alfāz al-Kitābiyyah. Edited by Emil Ya'qūb, (Beirut: Dar al-Kutub al-'Ilmiyyah, 1411 AH/1991 CE), p. 105.

Al-Tha'alibi, Abd al-Makek Ibn Muhammad (d. 429 AH/1038 C E), fiqh al-Lugha wa Asrār al-'Arabiyyah. Edited by Dr. Yasīn al-Ayyūbi, (Beirut: al-Maktabah al'Așriyyah, 1420 AH/2000 CE), p.180.

29 This word has two mentions in the singular form 'safih' (the Quran, 2: 282; 72: 4) and five mentions in the plural forms sufaha'' (the Quran, 2: 13, 142; 4: 5; 7: 155). The term is used in reference to sane people whose judgments are not right and sometimes used in a derogatory manner to accuse a person with imprudent judgments and unwise decisions.

30 Al-Bukhari al-Hanafi differentiates between insanity and stupidity; the first is inescapable and inevitable whereas the latter is a result of human heedlessness and ignorance. See, al-Bukhari, Kashf al-Asrār, vol. 4., p. 263. 
disability. In this context, it is highly important to consider their peaceful behavior and safety for all involved with them, and give due care for their best interests.

As far as the disability literature is concerned, disability has attracted many Muslim scholars over centuries. They discussed its related words and forms giving special attention to the moral behavior in response to disability and citing biographies of prominent disabled people since many of them showed exceptional talents and achievements. We can identify at least two main areas of authorship devoted to this issue:

- The Sharia-based discussions on disability: Sources of this literature are usually available in books of fiqh i.e. jurisprudence, and ușul al-fiqh i.e. the Principles of Muslim Legal Theories, and in hadith collections. ${ }^{31}$ For instance, various chapters of fiqh discuss the eligibility and legal competency of persons with disability to do certain acts, e.g. imamate, caliphate, adhan, and conclusion of financial and charitable contracts. Similarly, several chapters in hadith works celebrate the merits of persons with disability when they show determination and prove patient regardless of distressful afflictions. Imam al-Bukhari, for instance, devoted a full chapter for this purpose entitled "Kitāb al-Marda i.e. the Chapter on the Sick People" in which he narrated several prophetic statements on many issues, such as the reward of the sick people, the etiquettes of visiting them, the rewards for a person affected by the loss of sight or by epilepsy. ${ }^{32}$ Ibn Majah (d. 273 AH/886 CE) also has a chapter entitled "Kitāb al-Tibb" ${ }^{33}$ in addition to other subtitles on issues related to mental

31 For example, al-Bukhari al-Hanafi among several legists discussed the impediments of legal competency classifying them into the inevitably inescapable impediments and the acquired consequent impediments. The first category includes death, insanity, forgetfulness, and sickness whereas the second includes intoxication, stupidity, travel, and errors. See al-Bukhari, Kashf al-Asrār, vol.4., p. 263.

32 He also entitled the following chapter as "Kitāb al-Tibb i.e. Chapter on Medicine" including various topics related to diseases and ancient ways of medical treatment. See, al-Bukhari, Muḥammad Ibn Isma‘īl (d. 256 AH/870 CE), al-Jami ‘ al-Musnad al-Sahīh, (Riyadh: Ministry of Islamic Affairs and Awqāf, 1417 AH/1997 CE), pp. 1214-1221; pp. 1222-1240.

33 Ibn Majah, Muhammad Ibn Yazīd (d. 273 AH/886 CE), Sunan Ibn Majah. Edited by Muḥammad al-Rajihi, (Riyadh: Bayt al-Afkār al-Dawliyyah, undated), p. 372-383. 
disability, such as the divorce of a person with a weak mind. ${ }^{34}$ Other hadith works usually have scattered chapters on various medical issues, ways of treatment, and legal rulings related to medication that later formed the material of the literature of "al-Tibb al-Nabawi" as evinced in the books of $\mathrm{Abu} \mathrm{Nu}$ 'yam (d. $430 \mathrm{AH} / 1038 \mathrm{CE}$ ), al-Dhahabi (d. 748 AH/1348 CE), and Ibn al-Qayyem (d. 751 AH/1350 CE). ${ }^{35}$

- The literary works on disability: This genre of writing discusses the terminology, biographies, accounts, situations, and funny tales of persons with disabilities. Several books were written about the biographies of people with disabilities, relating their accounts, exploits, achievements, and funny spirit. For example, Amr Ibn Baḥr Ibn Maḥbūb al-Kenāni alJahiz (d. 255 AH/868 CE) - a famous Arab man of letters and essayistwrote "al-Burșān wal Urjān wal Umyān wal Hulān" in which he cited tens of great heroes, leaders, and speakers among the persons with disability. ${ }^{36}$ It should be noted that al-Jahiz himself had a kind of disability as he had frightening boggle-eyes. He proved to be an erudite, prolific, and notably writer and became one of the earliest advocates for greater acceptance of disabled people affirming that impairments or odd appearance "do not hinder an individual from being a fully active member of the community or bar him from importance offices." ${ }^{37}$ Likewise, Ibn Qutaybah (276 AH/889 CE), in his work "al-Ma'arif [i.e. the Areas of Knowledge]. cited different categories of persons with forms of disability in a chapter entitled "Ahl al 'Ahät i.e. people with disabilities", in which he mentioned the names of persons with disabilities, such as al-Burși.e. the leper, $a l$ - Urj i.e. the lame, al-Jud'i.e. the one-armed people, al-Summ i.e. the deaf, al- $\bar{U} r$ i.e. the one-eyed people, and "al-Makafif i.e. the

34 Ibn Majah, Sunan, p. 221.

35 See, e.g., Abu Nu'aym, Ahmmad Ibn 'Abdullah (d. 430 AH/1038 CE), al-Ṭibb alNabawi. Edited by Dr. Mușțafa Khedr, (Beirut: Dar Ibn Hazm, $1^{\text {st }}$ ed. 1427 AH/2006 CE); al-Dhahabi, Muḥammad Ibn Aḥmad (d. 748 AH/1348 CE), al-Ṭbb al-Nabawi. Edited by Aḥmad Ref'at (Beirut: Dar Ihyā̄' al-'Ulūm, 1410 AH/1990 CE); Ibn Qayyem al-Jawziyyah, Muhammad Ibn Abi Bakr (d. 751 AH/1350 CE), al-Ṭibb alNabawi. Edited by 'Abd al-Ghani 'Abd al-Khaliq, (Beirut: Dar al-Fekr, undated).

36 Al-Jaḥiz, Amr Ibn Baḥr Ibn Maḥbūb (d. 255 AH/868 CE). Al-Burșān wal Urjān wal Umyān wal Hulān, (Beirut: Dar al-J̄̄l, 1410 AH/1990 CE).

37 Albrecht, Gary L. ed. Encyclopedia of Disability: A History in Primary Source Documents. (London: SAGE Publications, 2006), vol. 1, p. 983. 
Sightless." 38 Al-Ḥasan Ibn Muhammad Ibn Habīb al-Naysabūri (d. 406 AH/1016 CE) also wrote "Uqalā'al-Majanin i.e. the Sane of the Insane" which is deeply related to mental disability. He examined the terms used for insanity and foolishness as well as for mad persons. He also cited the names of animal insanities and quoted several proverbs related to mental disability before mentioning the biographic accounts of tens of men and women from different Muslim territories, who were attributed to mental disability while their life had some wonderful events or they left wise statements. ${ }^{39}$ However, Abu al-Faraj 'Abd al-Raḥmān Ibn al-Jawzi alBaghdadi (d. 597 AH/1201 CE) — a famous Hanbali jurist and historian had the most remarkable contributions in this context. He authored "Akhbār al-Hamqa wal Mughaffalìn [The Tales of Fools and Idiots]", in which he explored various terms related to this area in twenty four chapters, ${ }^{40}$ including the meaning of hamaqa i.e. absurdity or foolishness, the names and characteristics of the fools, warning against friendship with them. He also cited the big names of the fools who happen to hold different official, religious, judicial or literary offices, such as the fool reciters, scribes, narrators, emirs, judges, writers, muezzins, preachers, and teachers concluding his work with a chapter on various funny stories and tales of imperfect mentality. ${ }^{41}$ Further to this point, in his work "Safwat al-Safwah", he devoted a number of chapters for some biographical accounts he named "Uqalā' al-Majanin" [i.e. the Sane of the Insane] in Medina, ${ }^{42}$ Basra, ${ }^{43}$ Baghdad, ${ }^{44}$ Jerusalem,${ }^{45}$ Syria,${ }^{46}$ and

38 Ibn Qutaybah, 'Abdullah Ibn Muslim (d. 276 AH/889 CE). Al-Ma'arif. Ed. Tharwat 'Ukashah, (Cairo: General Egyptian Book Authority, 1992 CE), p. 578-588.

39 Al-Naysabūri, Al-Hasan Ibn Muḥammad Ibn Habīb (d. 406 AH/1016 CE). Uqalā' al-Majanīn. Ed. Muḥammad al-Sa'̄id Basyūni, (Beirut: Dar al-Kutub al-'Ilmiyyah, $1405 \mathrm{AH} / 1985 \mathrm{CE})$.

40 Ibn al-Jawzi, p. 20.

41 See Ibn al-Jawzi, Abu al-Faraj 'Abd al-Raḥmān (d. 597 AH/1201 CE). Akhbār alHamqa wal Mughaffalīn, with a commentary by 'Abd al-Amīr Muhanna, (Beirut: Dar al-Fikr al-Libnāni, 1410 AH/1990 CE), p. 154-204. Ibn al-Jawzi also devoted a chapter for "Tasmiyat al-Umyān al-Ashräf i.e. Naming the notable blind people" in his work Talqīh fuhūm Ahl al-Athar'. See, Ibn al-Jawzi, Abu al-Faraj 'Abd alRaḥmān (d. 597 AH/1201 CE), Talqīḥ Fuḥūm Ahl al-Athar, (Beirut: Dar al-Arqam Ibn Abi al-Arqam, 1997 CE), p. 324.

42 Ibn al-Jawzi, 'Abd al-Raḥmān (d. 597 AH/1201 CE), Safwat al-Ṣafwah. Edited by Khalid Țursusi, (Beirut: Dar al-Kitāb al-‘Arabi, 1433 AH/2012 CE), p. 369. 
Egypt. ${ }^{47} \mathrm{He}$ also related the accounts of the sane females among the insane, who were noted for their good behavior and asceticism in Kufa and Basra. ${ }^{48}$ To conclude, the Muslim tradition is replete with various literary and religious works on disability and mental disability on particular, which provide rich sources for studies and partly portray the social and legal contexts of their life as well as the impression they left on writers, jurists, and historians. Before ending this discussion, it is worth mentioning that Muslim governments paid due attention to the welfare of people with disability. For instance, 'Umar Ibn 'Abd al-'Azīz (d. 101 $\mathrm{AH} / 720 \mathrm{CE}$ ) sent messages to his governors in the cities of the Levant commanding them to collect the names of blind and disabled people who cannot stand up in prayers. In response, they sent him a file with their names. He then appointed a guide for each blind and a servant for each two disabled persons to take care of them. ${ }^{49}$

49 Ibn 'Asaker, 'Ali Ibn al-Hasan (d. 571 AH), Tarikh Madīnat Dimashq. Edited by 'Umar al-'Amrawi, (Beirut: Dar al-Fekr, 1' ${ }^{\text {st }}$ ed. 1417 AH/1996 CE), vol. 45, p.218. 


\section{Mental disability and Islamic Jurisprudence}

Reviewing the Muslim jurisprudence reveals a deserved respect for persons with disability in general. There is no actual discrimination against them when a person has the mental eligibility and necessary qualifications for any right or position. Consequently, a person with a certain form of disability that does not hinder him/her from doing the duties of a certain office or job is eligible for that office or job. For instance, a blind person may declare adhan, lead prayers, teach students, recite the Quran, narrate prophetic hadith, conclude contracts of sales, and act as agent in financial and marriage contracts. ${ }^{50}$ Some jurists may express their dislike that a disabled person leads prayers in the presence of bodily abled persons of equal qualifications. But in case the blind, for instance, is more qualified for a duty, he is most welcome as the preferable choice. ${ }^{51}$ However, the juristic debates show somewhat keenness to choose the best candidates for public serious positions and offices, such as caliphs, governors, judges, etc. As such, they did not see a blind person eligible for such positions, a view aspiring for the most perfect choice, but in principle it goes against the guidance of Prophet Muhammad, who entrusted 'Abdullah Ibn Umm Maktūm with conducting the public affairs of Medina during the Battles of Uhud and al-Khandaq i.e. the Trench. ${ }^{52}$ However, the focus of this research

50 For the Hanafi and Maliki jurists, a blind person may conclude sales and act as agent but the Shafi'i jurists restrict the financial actions of the blind to salam sales only in which the full description of the sold object must be well defined in the contract itself. Imam Malik stipulates that someone shall be with the blind person to see the sold object. He also authorizes the contracts of an insane person if concluded at times of his accidental consciousness. See, Badr al-Dīn al-'Ayni, Maḥmūd Ibn Muḥammad (d. 855 AH/1451 CE). Al-Binayah Sharḥ al-Hidayah. (Beirut: Dar alKutub al-'Ilmiyyah, 1420 AH/2000 CE), vol. 8, p. 94; Ibn 'Abd al-Barr, Yusuf Ibn 'Abdullah. Al-Kafi fi Fiqh Ahl al-Madinah. (Riyadh: Maktabat al-Riyāọ al-Hadīthah, 1400 AH/1980 CE), vol.2, p. 731; al-Mawardi, 'Ali Ibn Muhammad Ibn Muhammad (d. $450 \mathrm{AH} / 1058 \mathrm{CE}$ ). Al-Hawi al-Kabīr fi fiqh al-Imam al-Shafi 'i. Ed. 'Ali Mu'awwaḍ and 'Adel 'Abd al-Mawjūd, (Beirut: Dar al-Kutub al-'Ilmiyyah, 1419 AH/1999 CE), vol. 5, p.339; al-Nawawi, Yahya Ibn Sharaf (d. 676 AH/1278). Raw dat al-Ṭalibīn wa 'Umdat al-Muftīn, (Beirut \& Damascus: al-Maktab al-Islami, 1412 AH/1991 CE), vol.4, p. 298.

51 Ibn Nujaym, Zayn al-Dīn Ibn Ibrāhīm (d. 970 AH/1563 CE). Al-Baḥr al-Ra ’iq Sharh Kanz al-Daqa'iq. Dar al-Kitāb al-Islami, undated, vol.1, p.369.

52 Abu Hatim al-Darimi, Muḥammad Ibn Hibban (d. 354 AH/965 CE), al-Sirah alNabawiyyah Wa Akhbār al-Khulafā'. (Beirut: al-Kutub al-Thaqafiyyah, $3^{\text {rd }}$ ed. 1417 AH), vol. 1, p. 220, 230, 256. 
is not the eligibility of persons with disability to various jobs and positions. Simply, there is no legal barrier that restricts any person from assuming a position, which s/he can undertake perfectly. The main of focus of this juristic discussion is to explore the ethico-legal questions related to people with disability in which their families are in a place of taking a serious decision with important effects on their life and future. As far as the acts of worship are concerned, it is well known that some acts of worship are physical, others are financial, and still others are partly physical and partly financial. However, the acts of worship in general are only mandatory upon certain elements, including the age, sanity, physical ability, and financial ability. In other words, the obligatory acts of worship are not compulsory upon children for they are under age excepting the zakah imposed on wealth. Nor are they obligatory upon insane and mentally retarded people for the condition of being sane is violated. However, when the physical ability is not perfect, the worship shall be performed as possible as can be. For example, a sick person, who cannot stand in prayer, may pray while sitting but the sick person who cannot fast may break fasting and feed a needy person for each day missed. Similarly, a person who has no wealth is free from the obligation of zakah and a person without physical and financial abilities is free from the duty of hajj until he has the physical, mental, and financial means. ${ }^{53}$ As far as the intellectual ability is concerned, no physical or partly physical act of worship is mandatory upon an insane person. ${ }^{54}$ Further to this point, an insane person is not required to make up the acts of worship s/he missed during his sickness and absence of sound mind unless he, for

53 It is not obligatory on the insane but the guardian may declare the intention of pilgrimage on behalf of him/her and accompany him/her during the rites of hajj to observe them and their hajj is valid. Nevertheless, this kind of hajj is not sufficient for the religious duty imposed on them and once a person recovers, he shall do the duty again. See, e.g., Ibn 'Abidīn al-Ḥanafi, Muḥammad Amīn Ibn 'Umar, (d. 1252AH/1836 CE), Radd al-Muhtār 'Ala al-Durr al-Mukhtar, (Beirut: Dar al-Fekr, 1412 AH/1992 CE), vol.2, p.467; Al-Ḥaț̣āb, Muḥammad Ibn Muhammad alMaghribi (d. 954AH/1547 CE), Mawahib al-Jalīl fi Sharh Mukhtașar Khalīl, (Beirut: Dar al-Fikr, 1412 AH/1992 CE), vol.2, p.487.

Al-Bukhari, 'Abd al-'Azīz Ibn Aḥmad (d. 730 AH/1330 CE), Kashf al-Asrār 'An Ușūl Fakhr al-Islam al-Bazdawi, (Beirut: Dar al-Kitāb al-'Arabi, undated), vol.4, p.122; Ibn Nujaym, Zayn al-Din Ibn Ibrahīm al-Hanafi (d. 970 AH/1563 CE), alBaḥr al-Ra ’iq Sharh Kanz al-Daqa'iq, Dar al-Kitāb al-Islami, undated, vol.2, p.340. 
instances, retains awareness and sanity during the time of duty e.g. prayers or fasting. ${ }^{55}$

However, there is a juristic difference as to the financial duties, such as zakah. According to the majority of jurists, the zakah is due on the wealth itself regardless of the legal competency of a person. So, the zakah is compulsory on the wealth of the insane and even on the wealth of minor orphans and children. For the Hanafis, they differentiate between the rights of people, i.e. debts, expenses and fines and the rights of Allah, such as zakah and vows. ${ }^{56}$ The first category must be repaid from the wealth of the insane whereas $z a k a h^{57}$ is not obligatory on the insane or on the minor, for having sound mind and major age are two conditions for legal duties. ${ }^{58}$ However, if a person with mental disability recovers for one day during the year, the zakah becomes obligatory on his wealth. ${ }^{59}$

As for other binding declarations and contracts, the person with mental disability is free from the liabilities related to the rights of other people. For instance, the divorce, gifts, or vows of the insane or mentally retarded person are not binding. ${ }^{60}$ The same moral attitude dominates the area of criminal law. If a person with mental disability steals, ${ }^{61}$ fornicates, commits

55 Evidently, the duty of praying is not required from an insane or mentally retarded person. See, e.g., Ibn Nujaym, al-Bahr al-Ra 'iq, vol.2, p.86; al-Ḥattāb, Mawahib alJalìl, vol.1, p.469.

56 Ibn 'Abidīn al-Hanafi, Radd al-Muhtār, vol.2, p.258.

57 Unlike zakat al-fitr, as some Hanafi jurists maintained that it is exceptionally mandatory on the insane and the mentally weal people but this view goes against the mainstream view of the Hanafi Scholars. See, e.g., Ibn 'Abidīn al-Hanafi, Radd alMukhtār, vol.2, p.259.

58 Al-Halabi, Ibrahīm Ibn Muhammad al-Hanafi (d. 956 AH/1549 CE), Majma‘ alAnhur fi Sharh Multaqa al-Abhur. Edited by Khalīl 'Imran, (Beirut: Dar al-Kutub al'Imliyyah, $1^{\text {st }}$ ed. 1419 AH/1998CE), vol.1, p.286.

59 Al-Halabi, Majma' al-Anhur, vol.1, p.286.

60 Yahya Ibn Sa'īd said, "As far as I know, the divorce of an insane or a mentally overcome person is not effective during their insanity or absence of mind. See, alAșbuhi, Malik Ibn Anas (d. 179AH/795 CE), al-Mudawwanah, (Beirut: Dar alKutub al-'Ilmiyyah, 1415 AH/1995 CE), vol.2, p.84.

61 Al-Kharāshi, Muḥammad Ibn 'Abdullah (d. 1101 AH/1690 CE), al-Sharh al-Kabīr 'Ala Matn Khalīl, (Beirut: Dar al-Fekr, undated), vol.8, p.101; Al-'Adawi, 'Ali Ibn Ahmad (d. 1189 AH/1775 CE), Hashiyat al-'Adawi 'Ala Kifayat al-Talib alRabbani. Edited by Yusuf al-Shaykh, (Beirut: Dar al-Fekr, 1414 AH/1994 CE), vol.2, p.332. 
adultery ${ }^{62}$ or kills, ${ }^{63} \mathrm{~s} /$ he is exempted from the prescribed penalties for these crimes. ${ }^{64}$ As such, an insane must not be flogged for fornication, stoned for adultery, or cut off in case of theft. ${ }^{65}$ Only the damages of his/her crime must be compensated according Imam al-Shafi'i, from his wealth i.e. the value of theft and the blood money in case of killing. Imam Malik held the view that the blood money must be paid by the family of the insane killer. ${ }^{66}$ The person with mental disability also has another privilege of being exempted from paying a share in the blood money in consolidation with his family in case a relative of his family commits manslaughter as the family must pay the blood money. ${ }^{67}$ As for the crime of illicit relations, if a man has sexual intercourse with a woman with mental disability, he must be punished but she is not only free from punishment but she is also entitled to get the sadāq proper for women similar to her social position. ${ }^{68}$ On contrast, if an insane has sexual intercourse with a sane woman, Abu Hanifah would not only relieve the insane man from the punishment but also the sane woman as well. ${ }^{69}$ Further to this moral attitude, the Islamic laws guarantees all financial rights to people with mental disability, such as the share of inheritance,

62 Al-Hattab al-Ru'ini, Mawahib al-Jalīl, vol.6, p.295.

63 Al-'Adawi, Hashiyat al-'Adawi, vol.2, p.282.

64 Al-Jundi, Khalīl Ibn Ishaq al-Maliki (d. 776 AH/1374 CE), al-Tawḍih fi Sharh alMukhtașar al-Far'i Li-Ibn al-Hajib. Edited by Aḥmad 'Abd al-Karīm, (Markaz Najībawayh li al-Makhțūtāt wa al-Turāth, $1^{\text {st }}$ ed. 1429 AH/2008 CE), vol.8, p.246.

Cf. al-Asbuhi, al-Mudawwanah, vol.4, p.534; al-Zabīdi, Abu Bakr Ibn 'Ali (d. 800$1397 \mathrm{CE})$, al-Jawhara al-Nayyera, al-Matba'ah al-Khayriyyah, $1322 \mathrm{AH}$, vol.2, p. 164.

66 Ibn Rushd, Muḥammad Ibn Ahmad (d. 595 AH/1198 CE), Bidayat al-Mujtahid Wa Nihayat al-Muqtașid, (Cairo: Dar al-Hadīth, 1425 AH/2004 CE), vol.4, p.179; alNafrawi, Aḥmad Ibn Ghanim (d. 1126 AH/1714 CE), al-Fawakih al-Dawāni 'Ala Resalat Ibn Abi Zayd al-Qayrawani, (Beirut: Dar al-Fekr, 1415 AH/1995 CE), vol.2, p.193; al-Qarāfi, Aḥmad Ibn Yusuf (d. 684 AH/1285 CE), al-Dhakhīrah. Edited by Muhammad Bukhubza, (Beirut: Dar al-Gharb al-Islami, 1994 CE), vol.12, p.273.

67 'Ulaysh, Muḥammad Ibn Aḥmad (d.1299 AH/1882 CE), Minaḥ al-Jalīl Sharh Mukhtașar Khalīl, (Beirut: Dar al-Fekr, 1409 AH/1989 CE), vol.9, p.147.

68 Saḥnūn Ibn Sa‘̄id, al-Mudawwanah al-Kubra lil-Imam Malik Ibn Anas, (Beirut: Dar al-Kutub al-'Ilmiyyah, 1415 AH/1994 CE), vol. 4, p. 509; al-Qayrawani, Khalaf Ibn Abi al-Qasim (d.372 AH/983 CE), al-Tahdhīb fi Ikhtișār al-Mudawwanah. Edited by Muḥammad al-Amīn, (Dubai: Dar al-Buhūth wa al-Dirasat, 1423 AH/2002 CE), vol.4, p.804.

69 'Abd al-Wahhab al-Maliki, Abu Muhammad Ibn 'Ali (d.422 AH/1031 CE), al-Ishraf 'Ala Masael al-Khilaf. Edited by al-Habib Ibn Ṭaher, (Beirut: Dar Ibn Hazm, 1420 AH/1999 CE), vol.2, p.856. 
marital gifts and alimony for wives, and the like. ${ }^{70}$ It is worth mentioning here that the laws of inheritance deprive a killer of inheriting his/her victim, ${ }^{71}$ but in case of the insane killer, s/he is still eligible to receive his/her share of inheritance according to the majority of Muslim jurists. ${ }^{72}$ In case of gifts and donations, the father or guardian of a person with mental disability shall accept and hold them on his/her behalf. ${ }^{73}$ In this context, several moral and legal questions are worthy of detailed discussions but the paper will focus on two issues of "sterilization" and "marriage" of persons with mental disability as examples for the moral juristic debate on persons with mental disability.

\section{Sterilization of persons with mental disability}

Families with members suffering from mental disability face some serious challenges after those members reach the age of sexual potency. Many questions are frequently raised by such families with mentally retarded men or women. For instance, they wonder whether they have a legal rightas guardians over persons with mental disability, to submit their mentally retarded women to hysterectomy i.e. a surgical removal of part or all of woman's uterus? ${ }^{74}$ Using intrauterine devices, injectable contraceptives, and oral contraceptives pose other questions whereas the act of castrating men or using male birth control methods of contraception affecting men's hormone to lower their sperm counts to exclude the possible pregnancy of their female partners are other pressing questions.

Such questions are conducive to very serious consequences, if we bear in mind that 10 percent of the world population or 650 million persons live with a disability. ${ }^{75}$ For example, in a country like the United States there is

\footnotetext{
70 Al-Mawsū 'ah al-Fiqhiyyah, (Kuwait: 1409 AH/1989 CE), vol.16, p.101.

71 Al-Tabrīzi, Muhammad Ibn 'Abdullah (d. 741 AH/1340 CE), Mishkāt al-Mașabīh. Edited by Jamal 'Aytāni, (Beirut: Dar al-Kutub al-'Ilmiyyah, 1422 AH/2001 CE), vol.6, p.212.

72 Al-Qari, 'Ali Ibn Sultan (d. 741 AH/1340 CE), Mirqāt al-Mafatīḥ Sharḥ Mishkāt alMașabịh. Edited by Jamal 'Aytāni, (Beirut: Dar al-Kutub al-'Ilmiyyah, 1422 AH/2001 CE), vol.6, p.212.

Mawsū'at al-Fiqh al-Mișriyyah, (Cairo: Ministry of Awqāf), vol.1, p.21. https://www.thefreedictionary.com/hysterectomy.

Narsimulu, Suresh M. Makvana, and Ankit P. Patel, "the Mental Health of People with Disability." The International Journal of Indian Psychology, vol. 3, issue 2, (January to March 2016): p.28.
} 
an estimated 1.5 million persons aged 6-64 years have Mental Retardation and the overall rate of mentally retarded persons was 7.6 cases per 1000 population. ${ }^{76}$ Actually, women and girls with mental disabilities are vulnerable to abuse. A survey in Orissa, India, found that $25 \%$ of women with intellectual disabilities had been raped and $6 \%$ of disabled women had been forcibly sterilized. ${ }^{77}$ For the Arab region, the cognitive disability fluctuates from $5.7 \%$ in Egypt to $14.5 \%$ in Qatar. $^{78}$

It is widely acceptable that persons with disability are more liable to sexual assault. The gravity of this vulnerability is manifested if we know that $36.6 \%$ of Arab women with disability and $49.2 \%$ of Arab men with disability are single-and their sexual desire never dies-whereas $17.5 \%$ of women are widowed and $4.3 \%$ are divorced compared to $0.6 \%$ and $1.2 \%$ of men respectively. ${ }^{79}$ In a word, there are thousands of persons with disability are most likely suffering the challenge of being abused. Meanwhile, their mental illness does not exclude their sexual desire. Ibn Qudamah al-Hanbali (d. 682 $\mathrm{AH} / 1283 \mathrm{CE}$ ) clearly states that the mental retardation only affects the faculty of reason but it does not exclude the sexual desire. ${ }^{80}$ Pilot studies show that the interest in sexual life among them is rather high whereas their knowledge on sex, contraception, social and biological sex roles is very low. ${ }^{81}$ Another side of the problem is the harmful effects conduced when, for instance, a menstruating woman with mental illness unconsciously taints her body, clothes, and furniture with her blood. ${ }^{82}$ This complicated situation with several thorny elements highlights the importance of this question from the legal and moral perspectives. In their response to the ethico-legal question of sterilization in general, Sheikh Jad al-Haqq 'Ali Jad al-Haqq - the former Grand Muftis of Egypt and Grand Sheikh of Al-Azhar and Professor Ahmad

\footnotetext{
76 https://www.cdc.gov/mmwr/preview/mmwrhtml/00040023.htm.

77 Narsimulu. The Mental Health of People with disability, p.28.

78 United Nations, Escwa. Disability in the Arab Region, 2018, p. 21.

79 United Nations, Escwa. Disability in the Arab Region, 2018, p. 58.

80 Ibn Qudamah al-Hanbali, Abdurraḥman Ibn Muhammad (d. 682 AH/1283 CE), alSharh al-Kabīr 'Ala Matn al-Muqni', Dar al-Kitāb al-'Arabi, undated, vol.8, p.496.

81 Kijak, Remigiusz, the Sexuality of Adult with Mental disability in Poland. Springer Sexuality and Disability (March 17, 2017):

https://www.ncbi.nlm.nih.gov/pmc/articles/PMC3659277/accessed Oct. 2018.

82 This notion appears in a question for the legal ruling on hysterectomy of a mentally retarded woman by her family. See, https://www.sistani.org/arabic/qa/0325/ accessed Oct. 2018.
} 
al-Tayyeb - the former Grand Muftis of Egypt and currently Grand Sheikh of Al-Azhar, maintained that sterilizing any of the spouses or both of them is forbidden in Sharia if it results in prevention of reproduction, be it by means of medicine or surgery. Only if any of the spouses with a genetic disease is proved to affect the future pedigree, sterilization is permissible and even becomes obligatory. Simply, blocking the means to evils is weightier than securing any likely benefits. ${ }^{83}$ The majority of scholars are in agreement that sterilization is forbidden unless otherwise is proved by a legal necessary excuse. For Imam al-Țayyeb, the mental, physical, and psychological diseases are legally acceptable excuses if proved by scientific methods but in such cases sterilization must be a temporary procedure to avoid any impending dangers. As such, a person may stop the effect of sterilization and have children in the future if the disease disappears. Only if it is proved that pregnancy would result in the mother's death, she may be sterilized permanently after the trustworthy physician affirms it. ${ }^{84}$

This legal stand is equally applicable to all people, be they bodily abled or mentally ill. Similarly, the Jordanian House of Fatwa did not consider the family's fears that their mentally-ill woman may become pregnant as a legal excuse for allowing hysterectomy, indicating that this surgical operation may even encourage criminals to violate and harm those girls. They also saw it the duty of parents and guardians to take care of their mentally retarded girls to avoid any extra harm adding that it is also the duty of the community to prevent any sexual assault through taking the necessary precautions and measures. ${ }^{85}$

For the act of castration, the ancient Roman laws allowed it and, in a sense, guaranteed castrates a kind of protection. After the Romans, as it was a priority to enforce sacred precincts for men, the Catholic Church's preference of castrated singers encouraged the deliberate creation of them.

83 Sheikh Jad al-Haqq 'Ali Jad al-Haqq, al-Fatawa al-Islamiyyah, (Cairo: Dar al-Iftaa, 1431 AH/2010 CE), vol.14, p.141; al-Ṭayyeb, Imam Ahmad Muhammad, al-Fatawa al-Islamiyyah. (Cairo: Dar al-Iftaa, 1431 AH/2010 CE), vol.27, p.220-221.

Al-Ṭayyeb, Imam Ahmad Muhammad, al-Fatawa al-Islamiyyah. (Cairo: Dar alIftaa, $1431 \mathrm{AH} / 2010 \mathrm{CE})$, vol.27, p.220-221.

General Iftaa Department, Decision No. 194/2/2014 on Rabi‘ al-Awwal 7, 1435 AH/January 9, 2014 CE on the following link: http://aliftaa.jo/Decision.aspx?DecisionId=243\#.XAVUG9szaJA, accessed on Nov. 2018 . 
Efforts had been made to distinguish Catholic Christianity from pagan and Jewish norms, which gave rise to the idea of voluntary celibacy to take place as a religious differentiating mechanism defined the place of castrates in society and culture. ${ }^{86}$ When it comes to Islam, the Islamic law firmly stands against castration. Prophet Muhammad is authentically quoted to forbid being celibate. When 'Uthman Ibn Maz'un asked for a permission to live in celibacy, the Prophet proscribed that and Sa'd Ibn Abi Waqqas used to say, "Had he given a permission to him ['Uthman], we would have got ourselves castrated." 87

Castration here is comparable to the Christian monasticism; it means the isolation of one's self from life and earthly desires. In this regard, the Quran states, "As for monasticism, they innovated it-We had not prescribed it for them," 88 so Prophet Muhammad said, "There is no monasticism in Islam" 89 and said, "Each people has their monasticism and the monasticism of my people is the jihad in the cause of God." 90 It is an encouragement of hard-work, active life, achievement, and liberation of the world, as Islam stands against idleness and empty lifestyle. Once a man visited the Prophet with his slave that he had castrated, then the Prophet set

86 Actually, Catholic Christianity was an heir of Ancient Rome but an antagonist of Roman beliefs; and heir of Jewish tradition but denied some Jewish elements especially in the -realm of ethics. For more details about this notion, see Crawford, Katherine. Eunuchs and Castrati: Disability and Normality in Early Modern Europe. (London \& New York: Routledge, 2018), pp.72-73.

Al-Bukhari, Muḥammad Ibn Isma‘īl (d. 256 AH/870 CE), al-Jami‘ al-Musnad alSaḥ̄h. Ed. Muḥammad Zuhair, Dar Tawq al-Najah, 1422, hadīth number: 5073, vol.7, p.4; Ibn Hanbal, Aḥmad Ibn Muḥammad (d. 241 AH/855 CE). Musnad alImam A hmad Ibn Hanbal. Ed. Shu'aib al-Arna'ūṭ and 'Adel Murshid. (Muassasat alResalah, 1421 AH/2001 CE), hadìth number: 1514, vol.3, p.100.

88 The Quran, 57: 27.

89 Al-Baghawi, al- Husain Ibn Mas'ūd (d. 516 AH/1122 CE). Sharḥ al-Sunnah. Ed. Shu'aib al-Arna'ūt and Muhammad Zuheir al-Shawīsh, (Damascus \& Beirut: alMaktab al-Islami, 1403 AH/1983 CE), vol.2, p.371.

90 Ibn Abi Shaybah, Abu Bakr 'Abdullah Ibn Muhammad (d. 235 AH/850 CE). AlKitāb al-Mușannaf fi al-Ahadīth wal Athar. Ed. Kamal Yusuf al-Hut, (Riyadh: Maktabat al-Rushd, 1409 AH), vol.4, p. 205 
the slave free a compensatory measure for the nasty act of castration that his master did. ${ }^{91}$

The Islamic stand in this situation is very straightforward and even applicable to all living beings. Ibn 'Umar narrated that the Prophet even forbade the castration of horses and animals. ${ }^{92} \mathrm{Ibn}$ 'Abbas held the view that castrating animals is a form of forbidden mutilation and a devilish act. ${ }^{93} \mathrm{Al}$ Awza' $\mathrm{i}$ - the famous Imam of the Levant, said, "They disliked to castrate any living reproductive being." 94 To conclude, it goes against the Islamic scriptures and ethics to castrate any living beings, especially humans or to sterilize them unless it is for a prevention of a very dangerous consequence conducive to death or lethal loss. This moral Islamic attitude embodies a fundamental stand regarding human rights and safety, even if the individual is unaware of those rights, which accords the United Nations Convention on the Rights of Persons with Disability, which obliged States Parties in article (23) to ensure that persons with disabilities, including children, retain their fertility on an equal basis with others. ${ }^{95}$

\section{Marriage of persons with mental disability}

Debates about the consent of people with high level mental disability are always raised. Evidently, the persons with mental disability cannot express their freewill. In this situation, it is necessary for their guardians to decide on their serious personal affairs and take care of their various needs. What matters most indeed is the benefits of the person in question. As such, if s/he has any trace of reasoning and can express their view, the guardian should consult them. In all cases, a fair and beneficial decision shall be guaranteed. Under the Islamic law, a mentally retarded person is regarded as

91 Ibn Majah, Muḥammad Ibn Yazīd (d.273 AH/887 CE). Sunan Ibn Majah. Ed. Muhammad Fuad 'Abd al-Baqi, Dar Iḥyā' al-Kutub al-'Arabiyyah, undated, vol.2, p.894.

92 Ibn Abi Shaybah, al-Kitāb al-Mușannaf, vol.6, p. 423.

93 The Quran, 4: 119; Ibn Abi Shaybah, al-Kitāb al-Mușannaf, vol.6, p.423.

94 Al-San‘ani, Abdurrazzaq Ibn Hammam (d. 211 AH/827 CE). Al-Mușannaf. Ed. Habīb al-Raḥman al-A'zami. India: The Scholarly Council. (Beirut: al-Maktab alIslami, $1403 \mathrm{AH})$, vol.4, p.457.

95 http://www.un.org/disabilities/documents/convention/convention_accessible_pdf.pdf. Retrieved Sep. 1, 2018. 
a minor. ${ }^{96}$ As such, According to the Hanafi and Shafi' $i$ jurists, a guardian may validly conduct the contract of marriage on behalf of a person with mental disability under his guardianship, whether his mental disability is congenital or acquired. ${ }^{97}$ According to the Shafi'i prominent mufti Ibn Hajar al-Haytami, a father of a grandfather is so affectionate to his daughter/granddaughter that they are keen to do what is in her best interest, so their consent is a condition for her marriage. ${ }^{98}$ Even a mature son may validly conduct the marriage of his mentally retarded mother if he finds that she is in need of marriage after being widowed or divorced. ${ }^{99}$ However, in the absence of a close guardian, the judge or the ruler shall undertake the duty of considering the best interest of a woman with mental disability, including her marriage. ${ }^{100}$

In other words, the guardian is authorized to consider the benefits of a woman with mental disability under his custody to secure her best interests. The same ruling is equally applicable to men with mental disability; their guardian shall consider their conditions and do what is in the best interest of them. In this sense, the Islamic jurisprudence even allows the marriage of a man with mental disability to a woman with the same illness. ${ }^{101}$ But it is invalid on the part of the guardian to give a woman with mental disability in marriage to a eunuch, impotent man, or a man with amputated male member. ${ }^{102}$ In case a sane person marries a woman with mental disability, he

96 Fawzia Afzal Khan, Kalpana Seshadri Crooks, eds. "Beyond the Hysterectomies Scandal”. In the Pre-Occupation of Post-Colonial Studies, (London \& Durham, Duke University Press, 2000 CE), p. 212.

Al-Kasani, Abu Bakr Ibn Mas'ūd al-Hanafi, Bada'i ‘ al-Șana'i 'fi Tartīb al-Shara 'i ', (Beirut: Dar al-Kutub al-'Imiyyah, 1406 AH/1986 CE), vol. 2, p. 241; Ibn Hajar alHaytami, Aḥmad Ibn Muhammad (d. 974 AH/1567 CE). Al-Fatawa al-Kubra. AlMaktabah al-Islamiyyah, undated, vol. 4, p. 98. Ibn Hajar al-Haytami, al-Fatawa al-Kubra, vol.4, p.98.

Al-Kalwazani, Maḥfūz Ibn Aḥmad al-Hanbali (d. 510 AH/1116 CE). Al-Hidaya 'Ala Madhhab al-Imam Aḥmad. Ed. 'Abdul-Latīf Hamīm and Maher Yasīn, (Muassasat Ghiras: 1425 AH/2004 CE), p. 384.

100 Ibn Hajar al-Haytami. Al-Fatawa al-Kubra, vol.4, p.297; Ibn Qudamah al-Hanbali, al-Sharh al-Kabīr, vol.7, p.396.

101 Al-Mirdawi al-Ḥanbali, Muḥammad Ibn Muflih (d. 763 AH/1362 CE). Kitāb alFurū '. Ed. 'Abdullah Ibn 'Abd al-Muḥsin al-Turki, (Beirut: Muassast al-Resalah: 1424 AH/2003), vol.8, p.294.

102 Ibn Muflih, Ibrahīm Ibn Muhammad (d. 884 AH/1479 CE). Al-Mubdi ' fi Sharh alMuqni ‘. (Beirut: Dar al-Kutub al-'Ilmiyyah, $1^{\text {st }}$ ed. 1418 AH/1997 CE), vol.6, p.175. 
must treat her fairly and kindly, giving her due share of provision, clothes, residence, and intimacy. ${ }^{103}$ Here, the Sharia is keen to guarantee her due marital and financial rights in case of marriage. Ibn Hazm even quotes 'Umar's statement that if a woman, after consummation, is proved to suffer from insanity, leprosy, or elephantiasis, she is still entitled to receive her mahr (an obligatory marital dowry that a man pays for a woman). ${ }^{104}$ This Sharia-based attitude is even manifest in case of intimacy outside marriage. For example, if a sane man has a sexual intercourse with a mentally retarded woman, she is not only free from blame but he must pay for her a mahr equal to that usually given to her peers. ${ }^{105} \mathrm{Al}$-Bukhari has a chapter entitled "la Yurjam al-Majnūn wal Majnūna [An insane man or woman is not punished by stoning]." ${ }^{106} \mathrm{He}$ refers to their being exempted from punishment in $h u d \bar{u} d$ i.e. prescribed penalties.

After marriage takes place, the guardian may find it harmful to the person under his custody. Then, the guardian can again terminate the marriage on the ground of securing the best interests of those under his custody. In case a person with mental ability recovers and retains mental powers, s/he has the option to continue this marriage or terminate it, ${ }^{107}$ but the decision whatever maybe will affect the financial rights of the other partner. It is necessary in all cases to be assured that the person with mental disability is peaceful and avoids violence; there is no expected harm to the other partner in marriage. The guardian should also consider their needs for sexual desire and their right to enjoyment. This comes in line with the United Nations Convention on the Rights of Persons with Disability, which stresses in article one the full and equal enjoyment of all human rights and

103 Cf. Ibn al-Bradhi'i al-Maliki, Khalaf Ibn Abi al-Qasim (d. 372 AH/983 CE). AlTahdhīb fi Ikhtișār al-Mudawwanah. Ed. M. al-Amīn, (Dubai: Dar al-Buhūth li alDirasat al-Islamiyyah, 1423 AH/2002 CE), vol.2, p.226.

104 Ibn Hazm, 'Ali Ibn Aḥmad Ibn Sa‘̄̄ò (d. 456 AH/1064 CE), al-Muhalla, (Cairo: Idarat al-Tiba'ah al-Munīriyah, $1352 \mathrm{AH})$, vol. 10, p. 109-110.

105 Al-Qayrawani, 'Abdullah Ibn Abi Zayd (d. 386 AH/996 CE). Al-Nawadir wal Ziyadat 'Ala Ma fi al-Mudawwanah Min Ghayriha Min al-Ummahat. Ed. Muhammad Hijji et al., (Beirut: Dar al-Gharb al-Islami, $1^{\text {st }}$ ed. 1999 CE), vol.14, p.266.

106 Al-Bukhari, Muhammad Ibn Isma‘īl (d. 256 AH/870 CE), al-Jami` al-Musnad alSạ̣̄ḥ, (Riyadh: Ministry of Islamic Affairs and Awqāf, 1417 AH/1997 CE), Kitāb al-Hudüd, hadìth Number: 6815, pp. 1429-30.

107 Ibn Muflih, al-Mubdi'fi Sharhal-Muqni', vol.6, p.162. 
fundamental freedoms by all persons with disabilities, including those who have long-term physical, mental, intellectual or sensory impairments while article twenty three provides that "States Parties shall take effective and appropriate measures to eliminate discrimination against persons with disabilities in all matters relating to marriage, family, parenthood and relationships."108 In a word, the traditional views of Muslim jurists correspond to the latest recommendations and conventions approved by the international community as evinced in the UN conventions.

${ }^{108} \mathrm{http} / / /$ www.un.org/disabilities/documents/convention/convention_accessible_pdf.pdf. 


\section{Conclusion}

After examining several situations and issues related to persons with mental disability, this paper concludes that the Muslim scholars paid due attention to people with disability in general and to people with mental disability in particular as evinced in the literature of Muslim Jurisprudence and legal theories, collections of hadìth, and the literary and historic works that recorded the biographies of such people. In this context, the paper has made several references to a number of books and chapters as seen in the first part of this paper.

As far as the Islamic laws are concerned, the stand of Islamic laws and Muslim jurists regarding the life and rights of people with mental disability is deeply appreciated and highly moral and human. The Islamic laws guarantee people with mental disability all financial rights, including the right to inheritance, marital gift in case of women, donations, and wills. Meanwhile, they relieve them from all physical acts of worship and from all physical duties, including prayers, fasting, and hajj. Only the financial duty of zakah must be paid by the guardian. Likewise, the guardian can act on their behalf as regards the payment of the values of sales, rent, damages, and or the like. The Islamic laws also exempted them from all prescribed penalties and punishments, such as imprisonment, expatriation, flogging, retaliation, etc.

What matters most is that the Islamic jurisprudence puts no restrictions on meeting the natural needs of people with mental disability. Rather, it makes it mandatory upon the guardians to do what is best for them, giving permission for guardians to get them married if it is possible for them- to enjoy their life and help them have a kind of spiritual satisfaction. The Islamic laws also strictly forbid any attempt to serialize the people with mental disability or to deprive them of the right to have children.

In a word, the Islamic laws consider the situation of people with mental disability giving them concessions and permissions unavailable for others while enforcing the Muslim community and government to assume their responsibility for providing a safely enjoyable life for persons with mental disability that guarantees them the fundamental human rights and to do the utmost for achieving what is in their best interest. This highly moral attitude goes in harmony with the latest conventions and agreements on the rights of 
people with mental disability in the last decades, especially the United Nations Convention on the Rights of Persons with Disability, which stresses in its preamble the universality, indivisibility, interdependence and interrelatedness of all human rights and fundamental freedoms and the need for persons with disabilities to be guaranteed their full enjoyment without discrimination. It also affirms that discrimination against any person on the basis of disability is a violation of the inherent dignity and worth of the human person. ${ }^{109}$ This clearly proves that the moral human attitude of Muslim jurists is in need of further studies and researches to unveil their visions and insights to the modern lawmakers and help humankind have a better legislative system defending all fundamental human rights and guaranteeing human dignity. As such, I plan to write more papers about the Islamic regulations and juristic views regarding various categories of people with disability from different approaches. I wish this paper paves the way for further deeper studies and proves helpful for having a brief guide about the Muslim literature on persons with disability and the rights guaranteed for them in Islam.

109 http://www.un.org/disabilities/documents/convention/convention_accessible_pdf.pdf. Retrieved on Sep. 12, 2018. 


\section{Bibliography}

- 'Abd al-Baqi, Muhammad Fuad, al-Mu 'jam al-Mufahras Li Alfāz alQuran al-Karìm, (Cairo: Mațabi' al-Sha'b, undated).

- 'Abd al-Wahhab al-Maliki, Abu Muhammad Ibn 'Ali (d.422 AH/1031 CE), al-Ishraf 'Ala Masael al-Khilaf. Edited by al-Habib Ibn Taher, (Beirut: Dar Ibn Hazm, 1420 AH/1999 CE).

- Abu Hatim al-Darimi, Muḥammad Ibn Hibban (d. 354 AH/965 CE), al-Sirah al-Nabawiyyah Wa Akhbār al-Khulafā'. (Beirut: al-Kutub alThaqafiyyah, $3^{\text {rd }}$ ed. $\left.1417 \mathrm{AH}\right)$.

- Abu Nu'aym, Ahmad Ibn 'Abdullah (d. 430 AH/1038 CE), al-Tibb al-Nabawi. Edited by Dr. Mușțafa Khedr, (Beirut: Dar Ibn Hazm, $1^{\text {st }}$ ed. $1427 \mathrm{AH} / 2006 \mathrm{CE}$ ).

- Al-'Adawi, 'Ali Ibn Ahmad (d. 1189 AH/1775 CE), Hashiyat al'Adawi 'Ala Kifayat al-Talib al-Rabbani. Edited by Yusuf al-Shaykh, (Beirut: Dar al-Fekr, 1414 AH/1994 CE).

- Al-Aṣbuhi, Malik Ibn Anas (d. 179AH/795 CE), al-Mudawwanah, (Beirut: Dar al-Kutub al-'Ilmiyyah, 1415 AH/1995 CE).

- Al-Baghawi, al- Husain Ibn Mas'ūd (d. 516 AH/1122 CE). Sharh alSunnah. Ed. Shu'aib al-Arna'ūt and Muhammad Zuheir al-Shawīsh, (Damascus \& Beirut: al-Maktab al-Islami, 1403 AH/1983 CE).

- Al-Bukhari, Muhammad Ibn Isma'īl (d. 256 AH/870 CE), al-Jami` al-Musnad al-Saḥịh. Ed. Muḥammad Zuhair, Dar Tawq al-Najah, 1422.

- Albrecht, Gary L. ed. Encyclopedia of Disability: A History in Primary Source Documents. (London: SAGE Publications, 2006).

- Al-Bukhari, Muhammad Ibn Isma‘īl (d. 256 AH/870 CE), al-Jami ‘ al-Musnad al-Saḥ̄ḥ, (Riyadh: Ministry of Islamic Affairs and Awqāf, 1417 AH/1997 CE).

- Al-Dhahabi, Muhammad Ibn Aḥmad (d. 748 AH/1348 CE), al-Tibb al-Nabawi. Edited by Aḥmad Ref'at (Beirut: Dar Iḥyā' al-'Ulūm, 1410 AH/1990 CE).

- Al-Fayrūzabadi, Majd al-Dīn Muḥammad Ibn Ya'qūb (d. 817 AH/1415 CE), Bașa'er Dhawi al-Tamyīz fi Lața'ef al-Kitāb al-'Azīz. Edited by Muhammad A. al-Najjār, (Cairo: Ministry of Awqāf, 1416 AH/1996 CE).

- Al-Fayyūmi, Aḥmad Ibn Muḥammad (d. 770 AH/1368 CE), alMișbāh al-Munīr fi Gharīb al-Sharh al-Kabīr. Edited by Dr. 'Abd al'Az̄īm al-Shinnāwi, (Cairo: Dar al-Ma'arif, $2^{\text {nd }}$ ed. undated). 
- Al-Halabi, Ibrahīm Ibn Muhammad al-Ḥanafi (d. 956 AH/1549 CE), Majma' al-Anhur fi Sharh Multaqa al-Abhur. Edited by Khalīl 'Imran, (Beirut: Dar al-Kutub al-'Imliyyah, $1^{\text {st }}$ ed. 1419 AH/1998CE).

- Al-Hamadhāni, 'Abd al-Raḥmān Ibn 'Isa, Kitāb al-Alfāz alKitābiyyah. Edited by Emil Ya'qūb, (Beirut: Dar al-Kutub al'Ilmiyyah, 1411 AH/1991 CE)

- Al-Hatțāb, Muhammad Ibn Muhammad al-Maghribi (d. 954AH/1547 CE), Mawahib al-Jalīl fi Sharḥ Mukhtașar Khalīl, (Beirut: Dar alFikr, 1412 AH/1992 CE).

- Al-Jahiz, 'Amr Ibn Baḥr Ibn Maḥbūb (d. 255 AH/868 CE). Al-Burșān wal Urjān wal Umyān wal Hulān, (Beirut: Dar al-J̄̄l, 1410 AH/1990 $\mathrm{CE})$.

- Al-Jundi, Khalīl Ibn Isḥaq al-Maliki (d. 776 AH/1374 CE), al-Taw dih fi Sharh al-Mukhtașar al-Far'i Li-Ibn al-Hajib. Edited by Ahmad Abd al-Karīm, (Markaz Najībawayh li al-Makhțūtat wa al-Turāth, $1^{\text {st }}$ ed. $1429 \mathrm{AH} / 2008 \mathrm{CE})$.

- Al-Kalwazani, Mạ̣fūz Ibn Aḥmad al-Ḥanbali (d. 510 AH/1116 CE), al-Hidaya 'Ala Madhhab al-Imam A hmad. Ed. 'Abd al-Latīf Hamīm and Maher Yasīn, (Muassasat Ghiras: 1425 AH/2004 CE).

- Al-Kasani, Abu Bakr Ibn Mas'ūd al-Hanafi, Bada'i' al-Șana'i' fi Tartīb al-Shara'i', (Beirut: Dar al-Kutub al-'Imiyyah, 1406 AH/1986 $\mathrm{CE})$.

- Al-Kharāshi, Muḥammad Ibn 'Abdullah (d. 1101 AH/1690 CE), alSharh al-Kabīr 'Ala Matn Khalīl, (Beirut: Dar al-Fekr, undated).

- Al-Mawardi, 'Ali Ibn Muhammad Ibn Muḥammad (d. 450 AH/1058 CE). Al-Hawi al-Kabīr fi figh al-Imam al-Shafi 'i. Ed. 'Ali Mu'awwaḍ and 'Adel 'Abd al-Mawjūd, (Beirut: Dar al-Kutub al-'Ilmiyyah, 1419 AH/1999 CE).

- Al-Mirdawi al-Hanbali, Muhammad Ibn Muflih (d. 763 AH/1362 CE), Kitāb al-Furū '. Ed. 'Abdullah Ibn 'Abd al-Muhsin al-Turki, (Beirut: Muassast al-Resalah: 1424 AH/2003).

- Al-Nafrawi, Ahmad Ibn Ghanim (d. 1126 AH/1714 CE), al-Fawakih al-Dawani 'Ala Resalat Ibn Abi Zayd al-Qayrawani, (Beirut: Dar alFekr, 1415 AH/1995 CE).

- Al-Naysabūri, Al-Hasan Ibn Muḥammad Ibn Habīb (d. 406 AH/1016 CE), 'Uqalā' al-Majanīn. Ed. Muḥammad al-Sa'īd Basyūni, (Beirut: Dar al-Kutub al-'Ilmiyyah, 1405 AH/1985 CE). 
- Al-Nawawi, Yahya Ibn Sharaf (d. 676 AH/1278). Raw dat al-Ṭalibìn wa 'Umdat al-Muftīn, (Beirut \& Damascus: al-Maktab al-Islami, 1412 AH/1991 CE).

- Al-Qarāfi, Ahmad Ibn Yusuf (d. 684 AH/1285 CE), al-Dhakhīrah. Edited by Muhammad Bukhubza, (Beirut: Dar al-Gharb al-Islami, $1994 \mathrm{CE})$.

- Al-Qari, 'Ali Ibn Sultan (d. 741 AH/1340 CE), Mirqāt al-Mafatīh Sharh Mishkāt al-Mașabịh. Edited by Jamal 'Aytāni, (Beirut: Dar alKutub al-'Ilmiyyah, $1422 \mathrm{AH} / 2001 \mathrm{CE}$ ).

- Al-Qayrawani, Khalaf Ibn Abi al-Qasim (d.372 AH/983 CE), alTahdhīb fi Ikhtișār al-Mudawwanah. Edited by Muhammad al-Amīn, (Dubai: Dar al-Buhūth wa al-Dirasat, 1423 AH/2002 CE).

- Al-Qayrawani, 'Abdullah Ibn Abi Zayd (d. 386 AH/996 CE), alNawadir wal Ziyadat 'Ala Ma fi al-Mudawwanah Min Ghayriha Min al-Ummahat. Edited by Muhammad Hijji et al., (Beirut: Dar al-Gharb al-Islami, $1^{\text {st }}$ ed. 1999 CE).

- Al-Ṣan'ani, Abdurrazzaq Ibn Hammam (d. 211 AH/827 CE), alMușannaf. Edited by Habīb al-Raḥman al-A'zami. India: The Scholarly Council. (Beirut: al-Maktab al-Islami, 1403 AH).

- Al-Sharabāṣi, Ahmad. Fi Alam al-Makfufìn, (Cairo: Maṭba'at Nahḍat Mișr, 1375 AH/1956 CE).

- Al-Ṭabari, Muḥammad Ibn Jarīr. Jami 'al-Bayān. Ed. Aḥmad Shaker, (Beirut: Muassasat al-Resalah, $1420 \mathrm{AH}$ ).

- Al-Tabrīzi, Muhammad Ibn 'Abdullah (d. 741 AH/1340 CE), Mishkāt al-Mașabịh. Edited by Jamal 'Aytāni, (Beirut: Dar al-Kutub al'Ilmiyyah, 1422 AH/2001 CE).

- Al-Ṭayyeb, Aḥmad Ibn Muḥammad, al-Fatawa al-Islamiyyah. (Cairo: Dar al-Iftaa, 1431 AH/2010 CE).

- Al-Tha'alibi, Abd al-Makek Ibn Muḥammad (d. 429 AH/1038 CE), fiqh al-Lugha wa Asrār al-'Arabiyyah. Edited by Dr. Yasīn alAyyūbi, (Beirut: al-Maktabah al-'Așriyyah, 1420 AH/2000 CE).

- Al-Zabīdi, Abu Bakr Ibn 'Ali (d. 800-1397 CE), al-Jawhara alNayyera, al-Matba'ah al-Khayriyyah, $1322 \mathrm{AH}$.

- Badr al-Dīn al-'Ayni, Maḥmūd Ibn Muhammad (d. 855 AH/1451 CE). Al-Binayah Sharh al-Hidayah. (Beirut: Dar al-Kutub al'Ilmiyyah, 1420 AH/2000 CE).

- Crawford, Katherine. Eunuchs and Castrati: Disability and Normality in Early Modern Europe. (London \& New York: Routledge, 2018). 
- Fawzia Afzal Khan and Kalpana Seshadri Crooks, eds. "Beyond the Hysterectomies Scandal”. In the Pre-Occupation of Post-Colonial Studies, (London \& Durham, Duke University Press, $2000 \mathrm{CE}$ ).

- Ibn 'Abd al-Barr, Yusuf Ibn 'Abdullah. Al-Kafi fi Fiqh Ahl alMadinah. (Riyadh: Maktabat al-Riyāọ al-Ḥadīthah, 1400 AH/1980 $\mathrm{CE})$.

- Ibn 'Abd al-Hadi, Yusuf Ibn Hasan (d. 909 AH/1503 CE), al-Durr alNaqi fi Shaḥ Alfāz al-Khiraqi. Edited by Raḍwān Gharbiyyah, (Jedda: Dar al-Mujtama', 1411 AH/1991 CE).

- Ibn 'Abd al-Raḥman, Abu al-Fatḥ al-'Abbasi 'Abdurrahimim (d. 963 AH/1556 CE). Ma'ahid al-Tanșiș Ala Shawahid al-Talkhīṣ, Ed. Muhiddīn 'Abd al-Hamīd, Beirut: 'Alam al-Kutub, undated.

- Ibn 'Abidīn al-Hanafi, Muḥammad Amin Ibn 'Umar, (d. 1252AH/1836 CE), Radd al-Muhtār 'Ala al-Durr al-Makhtār, (Beirut: Dar al-Fekr, 1412 AH/1992 CE).

- Ibn Abi Shaybah, Abu Bakr 'Abdullah Ibn Muhammad (d. 235 AH/850 CE). Al-Kitāb al-Mușannaf fi al-Ahadīth wal Athar. Ed. Kamal Yusuf al-Hut, (Riyadh: Maktabat al-Rushd, 1409 AH).

- Ibn al-Bradhi'i al-Maliki, Khalaf Ibn Abi al-Qasim (d. 372 AH/983 CE). Al-Tahdhīb fi Ikhtișār al-Mudawwanah. Ed. M. al-Amīn, (Dubai: Dar al-Buhūth li al-Dirasat al-Islamiyyah, 1423 AH/2002 CE).

- Ibn al-Jawzi, Abu al-Faraj 'Abd al-Raḥmān al-Baghdadi (d. 597 AH/1201 CE):

- "Akhbār al-Hamqa wal Mughaffalīn" with commentary by 'Ab al-Amīr Muhanna, (Beirut: Dar al-Fekr al-Libnāni, 1410 AH/1990 CE).

- Safwat al-Safwah. Edited by Khalid Țursusi, (Beirut: Dar al-Kitāb al-'Arabi, $1433 \mathrm{AH} / 2012 \mathrm{CE}$ )

- Talqīh fuḥum Ahl al-Athar, (Beirut: Dar al-Arqam Ibn Abi alArqam, 1997 CE).

- Ibn Hajar al-Haytami, Aḥmad Ibn Muḥammad (d. 974 AH/1567 CE). Al-Fatawa al-Kubra. Al-Maktabah al-Islamiyyah, undated.

- Ibn Hanbal, Ahmmad Ibn Muḥammad (d. 241 AH/855 CE). Musnad alImam Ahmad Ibn Hanbal. Ed. Shu'aib al-Arna'ūt and 'Adel Murshid. (Muassasat al-Resalah, 1421 AH/2001 CE).

- Ibn Hisham, al-Sirah al-Nabawiyyah. Ed. Mușțafa Al-Saqqa et al., (Cairo: Mușțafa al-Babi al-Halabi Press, 1375AH/1955 CE).

- Ibn Majah, Muḥammad Ibn Yazīd (d. 273 AH/886 CE): 
- Jad al-Haqq 'Ali Jad al-Haqq, al-Fatawa al-Islamiyyah, (Cairo: Dar al-Iftaa, $1431 \mathrm{AH} / 2010 \mathrm{CE}$ ).

- Sunan Ibn Majah. Edited by Muhammad al-Rajihi, (Riyadh: Bayt alAfkār al-Dawliyyah, undated) and another edition Edited by Muḥammad Fuad 'Abd al-Baqi, Dar Ihyā̄' al-Kutub al-'Arabiyyah, undated.

- Ibn Muflih, Ibrahīm Ibn Muhammad (d. 884 AH/1479 CE). AlMubdi 'fi Sharh al-Muqni'. (Beirut: Dar al-Kutub al-'Ilmiyyah, $1^{\text {st }}$ ed. 1418 AH/1997 CE).

- Ibn Nujaym, Zayn al-Dīn Ibn Ibrāhīm (d. 970 AH/1563 CE). Al-Bahr al-Ra'iq Sharh Kanz al-Daqa 'iq. Dar al-Kitāb al-Islami, undated.

- Ibn Qayyem al-Jawziyyah, Muḥammad Ibn Abi Bakr (d. 751 AH/1350 CE), al-Tibb al-Nabawi. Edited by 'Abd al-Ghani 'Abd alKhaliq, (Beirut: Dar al-Fekr, undated).

- Ibn Qudamah al-Ḥanbali, Abdurrahmman Ibn Muhammad (d. 682 AH/1283 CE). Al-Sharh al-Kabīr 'Ala Matn al-Muqni'. Dar al-Kitāb al-'Arabi, undated.

- Ibn Qutaybah, 'Abdullah Ibn Muslim (d. 276 AH/889 CE). AlMa'arif. Ed. Tharwat 'Ukashah, (Cairo: General Egyptian Book Authority, 1992 CE).

- Ibn Rushd, Muhammad Ibn Ahmad (d. 595 AH/1198 CE), Bidayat al-Mujtahid Wa Nihayat al-Muqtașid, (Cairo: Dar al-Hadīth, 1425 $\mathrm{AH} / 2004 \mathrm{CE})$.

- Illis Douek, Overcoming Deafness: the Story of Hearing and Language, (London: Imperial College Press, 2014 CE).

- Narsimulu, Suresh M. Makvana, and Ankit P. Patel. "The Mental Health of People with disability." The International Journal of Indian Psychology, Vol. 3, issue 2, (January to March 2016).

- Samuel M. Jackson, the Concise Dictionary of Religious Knowledge and Gazetteer, (New York: 1889).

- 'Ulaysh: Muhammad Ibn Aḥmad (d.1299 AH/1882 CE), Minaḥ alJalīl Sharh Mukhtașar Khalīl, (Beirut: Dar al-Fekr, 1409 AH/1989 CE).

- Websites:

- http://www.un.org/disabilities/documents/convention/convention_acc essible_pdf.pdf.

- https://en.wikipedia.org/wiki/Ludwig van Beethoven

- http://aliftaa.jo/Decision.aspx?DecisionId=243\#.XAVUG9szaJA.

- https://www.cdc.gov/mmwr/preview/mmwrhtml/00040023.htm 
- https://en.wikipedia.org/wiki/Taha_Hussein.

- http://www.hawking.org.uk

- https://www.thefreedictionary.com/hysterectomy.

- https://www.sistani.org/arabic/qa/0325/ 